$\underline{\text { Book Review }}$

\title{
Living A Feminist Life
}

Chin-Ju Lin ${ }^{1 *}$, Benny C. Lu ${ }^{2}$

Published: March 19, 2018

Book's Author: Sara Ahmed

Publication Date: 2017

Publisher: Durham: Duke University Press

Price: $\$ 26.95$

Number of Pages: 312 pp. paperback

ISBN: 9780822363194

A feminist and queer of colour, Sarah Ahmed lectured in Women's Studies at Lancaster University and was later appointed by Goldsmiths College, University of London. During 2016, however, Ahmed would resign from her post at Goldsmiths - in protest against institutional discrimination against sexual harassment. Coming from an interdisciplinary background, Ahmed has studied philosophy, women's studies, and cultural studies. Within all of these fields, she finds women of colour's writing most empowering and sees it as her genealogy (p. 15). This is the approach that she adopts in this book. Living a Feminist Life is her most recent work that has developed out of her previous series of books (Willful Subjects (2014) On Being Included (2012), The Promise of Happiness (2010), Queer Phenomenology (2006). But what distinguishes Living A Feminist Life from her previous work?

Firstly, Ahmed ardently pursues the feminist 'citation policy' (p. 15-16); citing only feminists—and women of colour in particular - to build up this book. She claims that citation is also a political standpoint for feminist writing and she aimed to focus upon those who are excluded by white-centric authorship - hence the title 'Feminist Life'. This book of everyday feminism is composed of three parts. The first part 'Becoming Feminist' describes Ahmed's experiences of growing up by adopting a feminist lens. In the first chapter, Ahmed describes her positioning as a brown girl growing up in Australia and Britain. She felt different; struggling to conform to the right names, right bodies, and the right gender. Ahmed also felt alienated by other's expectations of her; she would not feel like herself, to become as others expected. But when she started describing those problems, within the autobiographical logic of the book, she became the problem. Ahmed studied those problems, identified sources of injustice, and described how they shaped her feminist politics and practices in daily life. Chapter Two focuses on power and directions. 'How power works as a mode of directionality (p. 43)'. Power shapes norms, and norms shape direction: people expect girls and boys to follow norms that are heteronormative. As a girl who refused to be 'girly', Ahmed refrained from smiling and singing at parties and demonstrated unhappiness with those gendered norms. To others, the young Ahmed was showing her potential as a feminist killjoy, seeking solace in the sadness of feminist pedagogy, in the tradition of feminist writing pioneers such as Mrs. Dalloway by Virginia Woolf. Chapter Three raises the subject of wilfulness and feminist subjectivity through the lens of Steven Erikson's The Willful Child who did not do as her mother wished, so that when she became ill and was on her death-bed and then lowered into her grave, her arms always came out of the earth again. The wilful child never gave up, even after death. Wilfulness, as Ahmed frames it, is an explanation of disobedience, a feminist spirit, it describes women who never give up their will, never recede, always oppose. A wilful subject often causes violence. Violence is not only gendered: there is 
also the violence of enslavement, of colonisation, of empire, thus, women of colour continuously and consciously raise their arms to show their strength, to protest, and to support each other.

Part II on 'Diversity Work' provides an account of how sexism and racism at institutional levels estranges women of colour and explores feminist lives within university settings. The Amendment to the Race Relations Act in Britain in 2000 required all public organisations in the United Kingdom to have and to disseminate race equality policies. Some institutional appointments were then created to meet the legislation, often of women of colour who were expected to transform the institution, and work to promote diversity. Such diversity work is a wilful feminist work for Ahmed, however she described it as being like 'banging your head against a brick wall' (p. 138). The metaphor of 'walls' is a theme in this chapter and then throughout to the end of the book. For Ahmed, 'wall' is a metaphor of the hardness of the institution that is difficult to transform. Some examples of sexual harassment and citation cultures are also used to explain how white male privilege remains powerful in the academic system.

Part III is on 'Living the consequences'. How do feminist killjoys live? How do they come up against the walls that are built up by sexism, heterosexism and racism? In chapter 7, 'Fragile Connections', Ahmed looks into black queer feminists' fragile connections with the world. When Ahmed, as a queer, a brown feminist, and an immigrant daughter, comes up against the system, she is often thrown, shattered, fragmented, in pieces, broken. Broken stories are also a history of secrets; wilful subjects are often regarded as shameful. Ahmed is looking for a way in her book, to relate to this breaking without aiming for restoration. Chapter 8 is 'feminist snap': a snap is a sudden break. It occurs when feminists encounter the breaking point that she cannot accept. She snaps. She speaks up, she takes action, and she refuses to accept those unacceptable interactions. A snap might seem a break but it actually brings up new 'hap', argues the author. When feminists snap, snap and snap, we make collective snaps to form arms that support each other. Feminism is thus collective snaps.

Chapter 9 is about lesbian feminism. It is liberating for women as it points out the possibility of women's solidarity without men, following lesbian feminism of the 1970s. Heterosexuality comes up as a wall that bars and frustrates women's connections with each other. Lesbian women are wilful subjects who come up against heterosexism in their ordinary everyday lives. They are regarded as dangerous and threatening. Their wayward arms challenge the system, providing a space where women build shelters to support each other.

In conclusion, the killjoy survival kit and manifesto, as presented in Ahmed's book, provides practical tools for how to live a feminist life. The survival kit includes books, tools, time, life, permission notes, other killjoys, humour, feelings, bodies. Within the ten principles of the killjoy survival kit, Ahmed's main point is to encourage the feminist to stay critical to the world, and to be against conventional happiness as the world defines it, against institutions and jokes that are unjust, violent and unequal. Instead, killjoys are willing to break the bonds that are damaging to themselves, and to take 'hap', to craft a new life, new happiness.

Clearly, 'wilfulness' represents the most vital politics that Ahmed postulates in this book and this provides a theory of the everyday tactics for feminists and activists to fight the racist heterosexual normality in/outside the academy. Readers who are familiar with Ahmed's work thus can easily glean the ethos of wilfulness that went through her previous writing. It is passionate writing of 'becoming a wilful woman' (of colour or queer), on the one hand. On the other, it also resounds with the topical \#metoo movement as we witness many wilful women standing up to question and collapse the "wall" that was built to harass women as well as shut off and quieten women's voices of pain and anger. This is perhaps particularly pertinent to younger girls, and resonates with Ahmed's study of a young girl's arm from the grave, vividly symbolising young girls' wilful subjectivity that insists on being heard. Her wilful power can even break the ground of the grave after death. Interestingly this may also remind readers about Judith Butler's (2000) noted reading of Antigone, also a wilful girl from Sophocles's Oedipus, who insisted upon her own will to decide life and death, confronting the patriarchy that aimed to silence her. What differs between Butler and Ahmed is the 'affect' that the latter brings to light, which is more centred on anger and uncompromised emotions rather than on the power of mourning that Butler is presenting.

In short, this book is about how 'becoming a wilful woman' and why we might want to. It is not simply a book of theory, but a kind of manifesto, however, it is still not a book that can be digested easily by the general public in our view - given its highly performative writing style, complex ideas and argument. But this is a book dedicated to the feminists and activists that are looking for reflexive shared experiences, as bell hooks claims "everyone should read it." Some Western connotations for us are still revealed here, when reflecting upon our experiences in Taiwan. We perform the power of queer wilfulness perhaps from the perspective of being wilful when negotiating with power, rather than directly picking up weapons to bang the walls; we learned how to collapse walls from numerous strategic negotiations and co-operation in our many daily practices with patriarchal structures.

Lastly, Ahmed's 'no-white-male-authors' citational politics and her prioritisation of women of colour invites more debates. For instance, it reminds us of the activist Sunili Govinnage (2015) who started to question white authorship in the literature field, when she asked why only 3 out of 124 bestseller from the New York Times 2012 were written by non-white authors. 
For us, this book also actually brings to mind the great solidarity that western radical feminists have developed from the 1970s on, and the postcolonial critique of 'women' that Black feminists drove so assiduously. This reminds of us of the vitalities of feminism in which different standpoints of women can be communicated and debated, and the book animates the hope that women might break the walls between us and transcend our different standpoints.

Citation: Lin, C.-J. and Lu, B. C. (2018). [Review of the book Living A Feminist Life, by S. Ahmed]. Feminist Encounters: A Journal of Critical Studies in Culture and Politics, 2(1), 12. https://doi.org/10.20897/femenc.201812

Copyright (C) 2018 by Author/s and Licensed by Lectito BV, Netherlands. This is an open access article distributed under the Creative Commons Attribution License which permits unrestricted use, distribution, and reproduction in any medium, provided the original work is properly cited. 